\title{
"Pouco tenho a dizer além do que vai nestes sambas"':
}

o sujeito brasileiro e a suspensão da "promessa de felicidade" em algumas canções do primeiro LP de Chico Buarque

\section{MANOEL DOURADO BASTOS B* $^{* *}$}

\begin{abstract}
RESUMO: Chico Buarque de Hollanda, de 1966, primeiro LP gravado pelo cancionista, traz uma série de canções centradas na figura de indivíduos. Circulando entre as questões cotidianas de suas vidas, assim como entre o samba e a bossa nova, os indivíduos do primeiro disco de Chico Buarque apresentam-se como figurações singulares do sujeito brasileiro. Os antagonismos sociais que os caracterizam oferecem uma expressão histórica, como uma experiência musical dos traumas sociais vividos nos anos 1960 no Brasil. A partir da análise e interpretação de algumas canções desse primeiro LP, o texto mostra a suspensão da promessa de felicidade como a sedimentação do processo histórico no trabalho de Chico Buarque.

PALAVRAS-CHAVE: Chico Buarque de Hollanda (1966); suspensão da promessa de felicidade
\end{abstract}

\section{"I have little to say beyond what is contained in these sambas": the Brazilian subject and the suspension of the "Promesse du Bonheur" in some songs from Chico Buarque's first LP}

\begin{abstract}
Chico Buarque de Hollanda, 1966 first LP recorded by the songwriter, brings a lot of songs centered on the figure of individuals. Circulating among the everyday issues of their lives, as well as between samba and bossa nova, this individuals in the first disc of Chico Buarque presents themselves as singular figurations of the Brazilian subject. Social antagonisms that characterize them offer a historical expression, like a musical experience of social traumas experienced in the 1960s in Brazil. From the analysis and interpretation of some songs of that first LP, the text shows the suspension of the "Promesse du Bonheur" as the sedimentation of the historical process in the work of Chico Buarque.
\end{abstract}

KEYWORDS: Chico Buarque de Hollanda (1966), suspension of the "Promesse du Bonheur"

\footnotetext{
* O texto que segue retoma, com pequenas alterações, capítulo da tese de doutorado que defendi em 2009 sobre Chico Buarque e Paulinho da Viola. O título do artigo é uma frase retirada do texto de contracapa escrito por Chico Buarque para seu primeiro LP, de 1966.

** Manuel Dourado Bastos é Professor Adjunto do Departamento de Comunicação da Universidade Estadual de Londrina. E-mail: manoeldb@uol.com.br

BASTOS, Manuel D. "Pouco tenho a dizer além do que vai nestes sambas": o sujeito brasileiro e a suspensão da "promessa de felicidade" em algumas canções do primeiro LP de Chico Buarque. Música Popular em Revista, 


\section{Esperando, esperando, esperando}

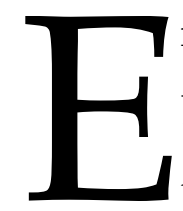

m "Pedro Pedreiro" (1965) 1, o característico esmero artístico de Chico Buarque, desdobrado como uma necessidade de sempre dar ótimo tratamento cancional a seu assunto, aparece na forma de reconhecer dignidade aos problemas de consciência do personagem principal da canção. Não é preciso muito esforço para encontrar em Pedro um "tipo social", que encarna não só o pedreiro, o operário da construção civil, mas sim toda uma classe - a dos explorados.

Nas angústias individuais de Pedro diante do sistema de cisão social à brasileira, deveria estar apresentada positivamente a consciência popular como um todo. Assim era de se esperar da apresentação de um "tipo social" em uma canção que guarda alguma filiação com a música engajada da época - a perfeita consecução de um assunto, a partir de sua apresentação típica, deveria demonstrar imediatamente o acerto da posição das forças populares diante da iniquidade do processo social. Neste sentido, "Pedro Pedreiro" convida a uma simpatia de esquerda, afinal seu assunto é absolutamente coerente com a dinâmica da "canção de protesto", inclusive no que tange a sua organização propriamente cancional.

Porém, sua dinâmica não é redentora, não justifica nos termos geralmente utilizados pela "canção de protesto" a esperança final, ainda que não apresente um fim de linha desastroso e definitivo. Além disso, o conflito entre seu assunto poético e sua formalização musical, como veremos adiante, termina por desmontar a lógica já frágil da fração da música engajada nos anos 1960 que não desvinculou interesse político e estilo bossanovista (ou ainda, que transformou a bossa nova em um estilo passível de sustentar, a contragosto e sem muita convicção, um discurso político que buscava inflamar a luta popular).

A canção em questão é um longo desfiar das angústias de Pedro, sua personagem principal. De início, o personagem é caracterizado por sua profissão e, por assim dizer, estado de espírito ("penseiro"); logo após, apresenta-se sua atividade

\footnotetext{
${ }^{1}$ Aponto entre parêntesis o ano de composição das canções. Vale lembrar, de qualquer modo, que as canções aqui analisadas foram gravadas no LP de Chico Buarque de 1966.

BASTOS, Manuel D. "Pouco tenho a dizer além do que vai nestes sambas": o sujeito brasileiro e a suspensão da "promessa de felicidade" em algumas canções do primeiro LP de Chico Buarque. Música Popular em Revista, Campinas, ano 2, v. 2, p. 7-36, jan.-jun. 2014.
} 
prosaica de esperar o trem, que será motivo alegórico ao longo da canção. O impulso inicial diante das alegorias é associá-las ao contexto político de ditadura civil-militar e logo suspeitar que a canção sopraria uma esperança de que aquele momento violento, taciturno e de liberdades (ainda não tão) restritas em que se encontraria o pensativo Pedro, passaria com a chegada de um novo trem, aquele que faria a espera (e o sofrimento) passar.

Para um momento em que parcela significativa da esquerda estava desnorteada diante da derrota que significava o golpe civil-militar de 1964, tal canção, entendida de maneira imediatamente alegórica, tomando por centro os pensamentos de um proletário, que não escondia em nenhum instante o desastre social brasileiro, mas que indicava um caminho positivo, seria mais que uma lufada de esperança seria o apontamento de que a certeza da vitória poderia virar uma convicção política.

Contudo, o vício de compreender a canção em relação imediata com o processo sócio-histórico deixa de observar aquilo que a canção aponta para além da contingência. Não resta dúvida de que o caráter alegórico da canção é forte e em boa medida lhe define o prumo, mas daí a definir sua fatura pela mera justaposição com os acontecimentos, sem nenhuma mediação crítica, desmereceria tudo o que ela pode nos levar a conhecer da história da época.

O que se configura em "Pedro Pedreiro"? Basicamente, a canção apresenta a configuração de um pensamento que se coloca diante da vida precária de um tipo social a partir de seu impulso contingente. Todo o desenrolar deste pensamento apresenta-se em conflito direto com as condições precárias de vida de Pedro, o que alça a canção a um movimento de totalização das condições de Pedro e retorno a um caráter individualista e privado. Para ser mais preciso, o pensamento de Pedro originase da "necessidade" imposta pelas condições precárias, como uma forma de esquecer a dureza do cotidiano ao mesmo tempo em que se reflete sobre ele, contrapondo-o.

Do ponto de vista literário, não há propriamente uma condenação pelo narrador deste ato do personagem esperar o trem, a manhã, o ano que vem, o sol, o carnaval, a festa etc., que podem ser entendidos como metáforas para o "dia que virá", conforme sua caracterização por Walnice Nogueira Galvão (1976). Inclusive, ao contrário do que poderia nos fazer supor a categoria de Galvão, a disposição passiva 
de Pedro, ainda que não seja propriamente desmerecida, é colocada em dúvida ao ser recolhida na estrutura geral de esbulho.

A crítica da canção reside, na verdade, no recurso da justaposição deste "dia que virá", que é algo que Pedro mal sabe o que é, porém deve esperar (não por moto próprio, decisão espontânea, mas pela compreensão que o narrador da canção tem do momento), com um "aumento" ou "bilhete pela federal", que o recolocam na roda da fortuna em outra posição, recusando a possibilidade de consciência que se avoluma pelo pensamento sobre aquilo que ainda não se sabe o que é. Ou seja, o "dia que virá", em "Pedro Pedreiro", também se mostra, por um lado, como uma farsa (ascender socialmente pela sorte) e, por outro, a mesma desgraça de sempre. Isso significa que o caráter do "dia que virá" não está decidido de antemão e, a se tirar pelo "ânimo" de Pedro, ele será o pior possível, principalmente porque o "trem" já vem.

Assim, estamos diante de um "tipo social” que não encarna imediatamente aquilo que deveria se esperar dele - a se tirar pelo estereótipo do povo insuflado rumo à revolução inexorável e vitoriosa da canção de protesto. Pedro não é só um "tipo social" singular, que age mecanicamente segundo o destino rumo à vitória, consciente de antemão de todo o processo; tampouco a consciência exterior do narrador lhe impinge uma guinada que lhe dê, sem volta e milagrosamente, o destino na mão.

Sendo um "tipo social" que caracteriza os explorados num emaranhado de contradições, Pedro expressa uma totalidade. A sociedade configurada em "Pedro Pedreiro" não tem necessariamente futuro redentor, ainda que a personagem (ao que parece, como frisa rapidamente o narrador) careça de uma manhã, aquilo que ele espera (melhor dizendo, sonha), mas que não sabe o que é, algo mais bonito que o mundo, maior que o mar - enfim, uma utopia, que contrasta com a materialidade prosaica do cotidiano de Pedro. Esta mesma sociedade que carece de mudança oferece a espera de uma festa, da sorte, da morte, de um retorno para o norte, bem como um filho (que continuará esperando) - em suma, momentos em que as iniquidades se repõem em novo formato. No campo daquilo que a sociedade oferece de forma imediata a Pedro, não há promessa de felicidade (Mas, qual promessa? Qual felicidade?).

O movimento de báscula dos problemas tomados por assunto na canção nos primeiros versos será repetido no desenrolar da canção. Após sermos 
apresentados a Pedro, o indivíduo que aglutina a abordagem da matéria, passamos para a elucubração do narrador em torno de suas necessidades (sociais? existenciais?) e chegamos à conclusão totalizante: o que quer que seja esta manhã (revolução? liberdade? justiça? bonança?) que Pedro carece de esperar, ela será benéfica a todos, tanto para os que têm bem quanto para quem nada tem. Trem e manhã aparecem como pares levemente sugeridos como contrários - o desenrolar da canção pode ser entendido como a rendição da manhã (e do sol), a que Pedro espera (ou carece de esperar), ao trem que, estranhamente, não leva ao movimento, mas à passividade. Um progresso que mantém tudo no mesmo lugar, fazendo do sonho com a manhã em mais uma espera que não leva a lugar algum.

A partir do problema particular de Pedro, caminha-se para uma totalização social, de modo que todo o desmanche apresentado ao longo da canção diz respeito não só ao indivíduo, mas à sociedade como um todo. O estrago se apresenta como algo generalizado - mas, apenas porque seu padrão de medida é o indivíduo (no caso, Pedro), o que retroage o impulso totalizador inicial.

Por isso, o "tipo social" não cumpre o papel esperado. À primeira audição, é como se o problema do indivíduo fosse mostrado para além de seu caráter particular, ou seja, em sua dimensão coletiva. Porém, o pensamento hesitante de Pedro diante da totalidade que se apresenta devolve tudo ao patamar do indivíduo, que assim fica na eminência de deixar passar o trem da história, levando consigo toda a coletividade (o sujeito histórico aglutinado no tipo). Ou seja, tudo depende de um acerto individual - já não é mais o destino inelutável do êxito que preside o argumento, porém ao custo de particularizar a questão até o indivíduo isolado em que o "tipo social" se transformou. Sendo um achado formal, já que escapa de um possível maniqueísmo redentor da inexorável vitória popular, ele perde exatamente o elemento de classe que está aglutinado ao "tipo social” em sua subjetividade, ainda que em geral isso seja redutor.

Para interpretar melhor esta questão, é preciso perceber que toda a narrativa de "Pedro Pedreiro" está assentada em uma construção musical de corte bossanovista, ainda que o naipe de percussão tenha uma bateria com maior volume do que o padrão, o que se junta com os ataques de metais que quase suplantam o 
violão, a voz e a flauta, estes todos em interpretação suave e que comandam o decurso cancional.

Nada disso está fora de esquadro, a se tirar pelo argumento apresentado até aqui. Lorenzo Mammì (1992) caracterizou de maneira acurada a bossa nova de Tom Jobim e de João Gilberto como um tipo de música calcada na "promessa de felicidade", a expressão de uma totalidade que se fia na reconciliação de contrários pela elevação da música local (o samba) ao patamar cosmopolita (o jazz) - acompanhando o "primado da melodia" nas composições de Tom Jobim e sua expressão exata na interpretação de João Gilberto, chegamos a compreender este "humanismo doce" reconciliatório que se promete como felicidade. A suavidade de voz e violão, mais as entradas da flauta transversal em diálogo com os anteriores, funcionam como a figuração da "promessa de felicidade" em "Pedro Pedreiro". Esta, por sua vez, é historicamente determinada - trata-se da "promessa bossanovista de felicidade".

Em um sentido abstrato, seguindo Mammì, esta "promessa de felicidade" dormita, por exemplo, nos tempos perfeitos aludidos pelo jogo de defasagem entre voz e violão na interpretação de João Gilberto, bem como nas consonâncias latentes no jogo dissonante do primado da melodia e sua ornamentação harmônica. Num sentido historicamente determinado, podemos sugerir que tal "promessa de felicidade" fundamenta-se no deslocamento do samba ao patamar cosmopolita do jazz (ao suprassumi-lo), o que vale pela concretização do ideal (desenvolvimentista) de pacificação de contrários (aquilo que Walter Garcia (1999) chamou da "contradição sem conflitos" em João Gilberto, ou seja, a reconciliação dos pares socialmente antagônicos sem o fim da desigualdade entre eles) - a mitigação das diferenças sociais derivaria da internalização do poder decisório, ou seja, a nação como elemento de mediação (e de reconciliação) de antagonismos. Um dos principais aspectos desta “contradição sem conflitos" está no caráter intimista da bossa nova (o "banquinho e violão"), que toma exatamente o indivíduo isolado como padrão último de medida, de onde se depreenderia imediatamente a totalidade em jogo nas canções.

Recentemente, Walter Garcia (2013) deu um passo na discussão sobre a "promessa de felicidade", a partir do aprofundamento do problema levantado por Lorenzo Mammì. Garcia se fixa em dar densidade ao contraste apresentado por 
Mammì entre a "vontade de potência" do jazz (especificamente na passagem do dixieland ao swing, entre a década de 1920 e 1930) com sua organização da big band e a promessa de felicidade da bossa nova com seus traços de intimidade e a "carga utópica" emanada pela temporalidade suspensa, lembrando ainda da "boemia cruel de Noel Rosa". Para Mammì (1992, p. 64), é como se os termos intimistas da bossa nova sinalizassem o "mal-estar de quem ficou suspenso entre uma antiga sociabilidade, que se perdeu, e uma definição nova, mais racional e transparente, que não conseguiu se realizar". O passo de Garcia está em observar essa "suspensão" segundo a categoria da cordialidade de Sérgio Buarque de Holanda - assim, a bossa nova seria uma utopia cordial, como se, enfim, estabelecesse uma relação de ambivalência, em que a modernidade é alcançada sem deixar para trás o aspecto aristocrático, colonial que é, enfim, a determinante da cordialidade. Walter Garcia insere em sua discussão o viés melancólico de João Gilberto, comumente ignorado pela crítica. Por fim, o que nos interessa particularmente, adensando o debate em torno da concepção de Antonio Candido sobre os "radicalismos", Walter Garcia aponta para certo caráter adocicado da radicalidade das canções de Chico Buarque, sustentada justamente por essa ambivalência cordial. ${ }^{2}$

Permanecem no trabalho de Chico Buarque os fundamentos desta "promessa de felicidade". Porém, eles entram em tensão com aquele outro aspecto compositivo, que é seu principal assunto, aquele do "tipo social" que é Pedro e sua espera. Por exemplo, há a espera da esperança aflita, bendita, infinita do apito do trem - esperar a esperança de um sinal é a migalha da "promessa de felicidade" que se oferece para Pedro. Por isso, também na organização musical da canção, a bossa nova não aparece em sua inteireza, vindo à lume entrecortada por elementos estranhos ao esperado.

\footnotetext{
2 Apenas para reforçar a questão, remeto a discussão para uma concepção diferente de "promessa de felicidade", ensejada pelos sambas de Paulinho da Viola. Mammì sustenta sua argumentação identificando João Gilberto como um "projeto utópico" - a "promessa de felicidade" em estado de suspensão histórica. Como em Paulinho da Viola o "povo" apresenta-se como o elemento determinante, a "promessa de felicidade" que nele também se apresenta não tem a característica de utopia, mas sim de esperança. Uma promessa de felicidade em negativo, em devir. A esperança de Chico Buarque e seu "Pedro Pedreiro" mantém uma ambivalência entre a utopia e o devir. Sobre Paulinho da Viola e o pressentimento da promessa de felicidade, publiquei recentemente um texto. Ver Bastos (2014).

BASTOS, Manuel D. "Pouco tenho a dizer além do que vai nestes sambas": o sujeito brasileiro e a suspensão da "promessa de felicidade" em algumas canções do primeiro LP de Chico Buarque. Música Popular em Revista, Campinas, ano 2, v. 2, p. 7-36, jan.-jun. 2014.
} 
Assim, tomando o indivíduo como parâmetro para a consecução formal e expressiva de sua matéria, Chico Buarque dá uma determinação histórica de longo alcance para seu problema. Em certo sentido, esta "promessa de felicidade" comparece também no elemento literário da canção. De fato, a mera "promessa de felicidade", em sua determinação bossanovista, reconciliada na matéria social da canção redundaria naquele "dia que virá”, acima referido conforme Walnice Nogueira Galvão (loc. cit). Contudo, o trabalho composicional de Chico Buarque não era descuidado. Tanto na letra quanto no trabalho musical, a "promessa de felicidade" é colocada em suspeita quer seja pelo fatalismo no "destino" de Pedro (ou seja, sabemos que o destino de Pedro é morrer, caso continue esperando, enquanto ganha alguns paliativos esperançosos, apresentados como variantes inócuas), quer seja pela irrupção de elementos musicais estranhos à economia de sons bossanovista.

Significa dizer que em "Pedro Pedreiro" a antinomia estética dá um passo rumo à suspensão da "promessa de felicidade" segundo seu caráter bossanovista. A "promessa de felicidade" não desaparece e continua operando conforme os seus desígnios de classe, mas aquele caráter ingênuo do "humanismo doce" é posto em suspenso ao ser colocado em contraste com o antagonismo social que pretendia reconciliar. De sorte que o povo, na figura de Pedro, que tende a um "tipo social", mas deve ser particularizado como indivíduo para poder vislumbrar uma nesga de esperança, está sempre aquém de seu papel histórico.

Do ponto de vista da experiência musical brasileira, estamos diante da suspeição crítica sobre sua própria dinâmica; o resultado sintético alcançado com a bossa nova é reaberto para nova avaliação, ainda que ao preço de continuar tomandoa como padrão de medida. Nisto a obra de Chico Buarque difere daquela de seus pares, que ou fizeram a mera justaposição de bossa nova e matéria social ou renegaram sem mais a bossa nova. Tratava-se de entender as fraturas da bossa nova a partir da verdadeira prova dos nove: a saber, confrontá-la consigo mesma, colocar em contraste sua fatura com seus pressupostos. 
Sugeri anteriormente que uma das marcas dos primeiros quatro discos de Chico Buarque é a comiseração. ${ }^{3}$ Esta dimensão formal apresenta o fosso político (consolidado pela ditadura civil-militar) entre a intelectualidade de esquerda e o "povo", na medida em que a primeira só consegue se aproximar do segundo pelo condoimento. A constatação do antagonismo social redunda em um engessamento do "povo", transformado em uma categoria histórica diante da qual a "promessa de felicidade" deságua na mais absoluta falta de esperança, ainda que terna, caridosa, em estado de consternação.

Não deixa de ser uma expressão de época esta fatura cancional. Ainda que assentada na mais pura ingenuidade bem informada, o elemento formal da comiseração figura o despreparo da esquerda órfã do nacional-desenvolvimentismo diante da ditadura civil-militar, em que a suspensão da "promessa de felicidade" indica o estado apoplético de quem deveria dar combate à tragédia que se desdobrava diariamente.

Em "Pedro Pedreiro", a relação mais complexa entre narrador e personagem, bem como os contrastes do aspecto musical, fazem com que esta suspensão adquira um caráter mais agudo, ainda que centrada no indivíduo, o que mantém acesa a chama da comiseração. A fratura social, politicamente intransponível nos casos interpretados no texto citado (salvo para o sentimento de comiseração, que o transpõe sem confrontá-la), é suturada não pela reconciliação pacificadora, mas pela consciência do beco sem saída em que todos se encontravam naquele momento e que exigia crítica urgente.

A centralização no indivíduo, que fica a um passo de figurar a totalidade social nos termos de um sintoma, força o achado ao patamar da comiseração, mas deixa a "promessa bossanovista de felicidade" sem chão histórico, exatamente porque, em seus próprios termos, o desdobramento cancional não tem consecução positiva. Ainda que limitado, o achado estético é poderoso.

\footnotetext{
${ }^{3}$ Inicialmente desenvolvi o argumento a partir da noção de "solidariedade piedosa" (BASTOS, 2006). Ao desenvolver a tese de doutorado (BASTOS, 2009), de onde retirei o presente texto, passei a entender a "solidariedade piedosa" a partir do princípio cristão da "comiseração".

BASTOS, Manuel D. "Pouco tenho a dizer além do que vai nestes sambas": o sujeito brasileiro e a suspensão da "promessa de felicidade" em algumas canções do primeiro LP de Chico Buarque. Música Popular em Revista, Campinas, ano 2, v. 2, p. 7-36, jan.-jun. 2014.
} 


\section{O samba vem aí}

Em "Olê olá" (1965), uma das primeiras canções de sucesso de Chico Buarque, alude-se à canção como um espaço ainda possível de felicidade - mais ainda, como a própria "promessa de felicidade" . ${ }^{4}$ A voz enunciativa da canção também avisa que este espaço possível de felicidade não se trata de um tipo de canção qualquer, mas sim de uma forma de canção determinada - o samba. Em tempos de clausura, na falta de liberdade e felicidade na vida imediata, esta canção apresentava-se como o momento de dizer ainda que se tinha o samba e, prestando atenção nele, não só se manteria a esperança, como se tornaria possível suspender as proibições e controles, especialmente naquele momento de regime militar.

O samba em "Olê olá" se organiza não apenas como o anúncio da felicidade, menos ainda como um refúgio para tempos sombrios, mas como um modelo de felicidade, disponível e abundante, que precisa ser agarrado a qualquer custo enquanto não percebia isto e não se "engajava" no samba, o "povo" corria o risco de continuar preso ao mundo opressivo do trabalho, ainda mais em sua contingência violenta de ditadura militar. Samba e povo, aí, não se identificam de imediato. A condição de realização da promessa (o momento em que não será mais necessário chorar) se daria apenas quando a felicidade viesse a se reconhecer no samba. Porém, esta relação de identidade entre samba e felicidade (que não é imediata) dependia da aderência do povo ao samba e seu universo. De fato, trata-se de uma mediação: a felicidade precisa se reconhecer no samba, mas só o fará se o povo se reconhecer nele, ou seja, se o povo tomar consciência de si.

Diante da hipótese de que no samba estaria a resposta para a felicidade, o sambista convida em "Olê olá" sua amiga-ouvinte a se "engajar" no samba em vez de entregar os pontos e chorar. Porém, o que se ouve na canção é um desenrolar de esperança, promessas e a decepcionante frustração no final - o samba não encontra mais espaço, o povo não se "engaja" nele, não há nem mesmo quem mantenha seu

\footnotetext{
${ }^{4}$ Walnice Nogueira Galvão (1976) já havia emitido argumento crítico sobre a condição utópica da promessa de felicidade com a ideia do "dia que virá". Ao longo do texto, perceberemos que a promessa de felicidade definida nos termos das canções de Chico Buarque se determinam por essa dimensão proposta por Galvão.

BASTOS, Manuel D. "Pouco tenho a dizer além do que vai nestes sambas": o sujeito brasileiro e a suspensão da "promessa de felicidade" em algumas canções do primeiro LP de Chico Buarque. Música Popular em Revista, 
anúncio ao cantar e o luar dá lugar para uma manhã em que o samba se perdeu; enfim, a amiga-ouvinte "já pode chorar". Significa dizer que a experiência histórica abria naquele instante uma brecha para o samba, tal uma "promessa de felicidade", acabar com a dor e se realizar - mas, esta chance foi perdida, afinal o sol chegou primeiro e a ausência do povo deixou o samba sem seu conteúdo próprio.

Se avaliarmos todo o decurso musical - o dedilhado das notas de encadeamento no registro grave e também do restante dos acordes ao violão, mais a voz de Chico Buarque no início, desdobrados todos num acompanhamento mais ao estilo bossanovista, somados a uma bateria, flauta e metais no decorrer da canção, quando a tessitura musical se adensa e se avoluma, porém constantemente interrompida pela tristeza do conjunto inicial - perceberemos que "Olê olá" é uma canção que busca manter acesa a "promessa de felicidade" no exato instante em que reconhece sua frustração historicamente determinada.

Repare-se que a canção começa como se fosse uma resposta do sambista a uma súplica da amiga-ouvinte - já pronta para chorar, avisa que irá fazê-lo ao sambista, que retruca com um dedilhado no violão e um canto de esperança; o esfacelamento desta diante de todos indica um fim de linha. Assim, ficou no passado o apontamento de que o samba é o espaço possível da felicidade, sua promessa, de cuja ausência a amiga-ouvinte possivelmente se ressente e pela qual suplica, e que só seria cumprida se o povo, reconhecendo-se no samba, tomasse consciência de si, em vez de se encaminhar ao mundo do trabalho e ao silêncio imposto não só por ele, como também pelo governo ditatorial-militar.

Não há propriamente resignação na canção, mesmo com o final desconsolado, mas tampouco há um obnubilamento diante da contingência. E, se levarmos em conta que o samba é um resultado da experiência popular, "Olê olá" sugere que a "promessa de felicidade" só será reatada se o povo for tomado como seu princípio fundamental - a bossa nova revelava-se como o limite para a compreensão da relação entre povo e "promessa de felicidade", a não ser quando ela surge a partir de uma autorreflexão.

Desde um ponto de vista imediatamente relacionado ao contexto histórico, a oportunidade de realizar a "promessa de felicidade" estava perdida naquele BASTOS, Manuel D. "Pouco tenho a dizer além do que vai nestes sambas": o sujeito brasileiro e a suspensão da "promessa de felicidade" em algumas canções do primeiro LP de Chico Buarque. Música Popular em Revista, Campinas, ano 2, v. 2, p. 7-36, jan.-jun. 2014. 
momento, mostrando-se cindida em seus próprios termos, dada a lacuna entre a bossa nova e o povo - como este poderia tomar consciência de si por meio daquela, se a autodeterminação ficava duplamente impossibilitada, tanto pela contingência histórica (a ditadura) como pela forma (a bossa nova) por meio da qual ela chega a si? Isto está apontado na canção que, dada sua perenidade, continua ressoando a promessa ao mesmo tempo em que ela está historicamente desacreditada pela antinomia entre forma e conteúdo. A "promessa de felicidade" permanece, porém os termos em que ela se apresenta mostram seu limite.

\section{O bom samba não tem lugar nem hora}

O limite antinômico da autodeterminação popular (o samba consciente de si) também é o mote de “Tem mais samba” (1964): “Vem que passa/Teu sofrer/Se todo mundo sambasse/Seria tão fácil viver". A afirmação é categórica: ela aponta para o samba como o espaço da felicidade; logo, para o povo como centro da felicidade. Porém, não é estranho perceber que em "Tem mais samba”, há samba propriamente dito em diversos lugares (a letra é recheada de referências, diretas e indiretas, a ele), menos no desenvolvimento musical da canção ela mesma - a não ser em seu final, quando a música já vai sumindo em fade out, o acompanhamento passa a se organizar num samba com surdo e tamborim, mais um coro de "pastoras" cantando o refrão. Estamos diante de um exemplo da dificuldade em dar forma ao seu conteúdo.

Talvez um pouco do anedotário de Chico Buarque ajude-nos a compreender o problema. Conta-nos Humberto Werneck que em dezembro de 1964 estrearia o musical "Balanço de Orfeu”, produzido por Luiz Vergueiro, que é quem lembra a história. A narrativa é recheada de lances divertidos e explicativos - quer dizer, as diversas peripécias em torno da encomenda que Luiz Vergueiro fez para que Chico Buarque compusesse a música que daria o fecho ao espetáculo.

A primeira parte do show, $\mathrm{Na}$ onda do balanço, seria como um diálogo entre a Bossa Nova e a nascente Jovem Guarda, na qual muitos viam inquietante ameaça à música brasileira. De um lado, o jovem cantor Taiguara, de outro, uma cantora que acabaria não seguindo carreira, Claudia Gennari. Ele 
"engajado", ela "alienada", conforme o imperioso jargão da época. No final, previsivelmente, triunfaria a Bossa Nova - e, para que não pairasse dúvida, a moral da história seria resumida numa canção, a tal encomendada a Chico, a ser cantada por todos os participantes do espetáculo (WERNECK, 1989, p. 11).

Depois de narrar o périplo algo engraçado de um Chico Buarque bêbado e mal dormido para entregar a encomenda em tempo, Werneck revela que esta canção é “Tem mais samba”.

O biógrafo é categórico: “Tem mais samba” serviria como o desfecho moral da disputa entre bossa nova engajada (portanto, a "canção de protesto") e jovem guarda alienada. Seu conteúdo, portanto, é político. Ela estava designada para transmitir a mensagem do engajamento e Chico Buarque encontrou a solução na eleição do samba como a matéria que daria consecução exata ao engajamento como posição política avançada, que era a moral do fim do espetáculo. Este conteúdo deveria se amalgamar com a forma da bossa nova, que era a expressão musical a partir da qual o engajamento seria transmitido. Assim, o espetáculo teria seu final garantido.

Mas, nem só das intenções do compositor vive uma canção, menos ainda da transmissão de mensagens. É preciso compreendê-la em seu nexo cancional para além da primeira impressão de superfície, em que forma e expressão se organizam de maneira mais profunda - ainda que a indústria cultural a leve de volta ao chão. Adélia Bezerra de Meneses aponta para a conjuração do sofrimento, bem como para a anulação da distância como substâncias poéticas da canção:

\footnotetext{
E naquilo que o poeta fala que "tem mais samba" (...) podemos apontar que se privilegia aquilo que é mais concreto, que se aproxima mais da viabilidade de um contato, tudo aquilo que anula a distância. Assim, privilegia-se o encontro, em detrimento da espera (que é virtualidade); o porto, lugar da chegada, e não a vela; o perdão (possibilidade de reencontro) e não a despedida, que é separação, etc. "Tem mais samba nas mãos do que nos olhos": aqui também o critério do contato e da materialidade dominou. As mãos, órgãos do tato, entram em contato com a matéria, a nível de pele, e de seu objeto apreendem uma gama de sensações: textura, calor e frio, umidade e secura, maciez e rigidez. O olhar é mais "espiritualizado" do que o tato. "Tem mais samba" aquilo que é mais concreto; que propicia a possibilidade de uma transmissão energética, a nível de corpo.

Vejamos onde mais radica essa "concretude": no chão, no som que vem da rua, no homem que trabalha: preocupação com o 'popular' na lírica de Chico Buarque? Mas o que importa aqui é que "samba" é sinônimo de amor e felicidade, e "sambar" é a grande proposta do poeta (MENESES, 2000, p. 52 53-54).
}

BASTOS, Manuel D. "Pouco tenho a dizer além do que vai nestes sambas": o sujeito brasileiro e a suspensão da "promessa de felicidade" em algumas canções do primeiro LP de Chico Buarque. Música Popular em Revista, Campinas, ano 2, v. 2, p. 7-36, jan.-jun. 2014. 
A anulação da distância, o contato, dar-se-ia pela força do concreto como substância motriz da canção, segundo Adélia Bezerra de Meneses. Mas, ainda que se proponha a anulação da distância, a se tirar pelo argumento da autora, o concreto, ele mesmo, estaria cindido em pedaços. Inicialmente, a autora firma certeza em um aspecto do concreto, o nível corporal em que se opera o contato, depois de apresentar outras facetas dele. Logo após, somos apresentamos a outra possibilidade deste concreto, que é a "preocupação com o popular". Nesta, por sua vez, a autora não firma certeza: diante da evidência, anunciada em versos como "Tem mais samba no homem que trabalha / Tem mais samba no som que vem da rua", a autora se contenta com uma indagação: “preocupação com o 'popular' na lírica de Chico Buarque?”. Aquilo que nos apareceu logo acima como conteúdo da canção é posto em suspenso (entre aspas), com uma pergunta que indaga sobre o sentido de um propósito como este. Não é de se admirar que a autora fique com a alternativa "corpórea" do concreto, em que a subjetividade se dá pelo contato sentido pelo indivíduo, deixando para o campo da ausência de sentido o conteúdo social da canção - para Adélia Bezerra de Meneses, samba é amor e felicidade, é, enfim, afeto, donde se origina a proposta (política?) de Chico Buarque, mas causaria estranheza ser uma preocupação popular.

Não é para sugerir que o samba não deva ser compreendido como amor e felicidade ou seus contrários, enfim, como afeto, que será desenvolvido o argumento daqui por diante. Muito pelo contrário. Mas, é preciso apontar como fraturada, ou desorganizada de um ponto de vista lógico, a assertiva de que a canção que tem por princípio poético a anulação da distância se resolva na cisão do concreto em sensações corpóreas, de um lado, e preocupação com o popular, do outro, com ascensão das primeiras em detrimento da segunda.

O problema, claro, não é lógico, mas histórico. Assim, podemos observar a contradição em jogo na relação entre a aproximação pelo concreto e sua cisão interior como a revelação histórica de "Tem mais samba". O corpo, na maneira como foi aludido por Adélia Bezerra de Meneses, aponta para a subjetividade centrada no indivíduo, com o que a autora garantiria a comprovação do lirismo absoluto das canções de Chico Buarque, porém sob pena de desprezar parcela significativa da 
canção, aquilo que lhe foi designado como conteúdo, a "preocupação com o popular", e que lhe exige por dentro soluções formais e expressivas. No esforço de fechar análise sobre Chico Buarque sob os desígnios do eu-lírico fixado na subjetividade do poeta, a autora deixa escapar o aspecto antinômico da obra a sua frente. Ao dar atenção para a totalidade da canção (e não apenas para sua dimensão literária), atinamos com a determinação histórica da canção.

Não é preciso muito esforço para reconhecer a bossa nova como um elemento formal da canção, mas não custa relembrar o anedotário biográfico de Humberto Werneck para ressaltar que este é seu escopo compositivo imediato. Notamos mais acima que em "Tem mais samba" o samba funciona mais como seu conteúdo do que como expressão musical, exceto ao final da canção. O cerne expressivo da canção está na bossa nova, já mediada por sua derivação engajada. $\mathrm{O}$ samba é matéria da canção, mas não consegue se sustentar como forma e expressão a não ser como um apontamento para além da própria canção. A dinâmica cancional de "Tem mais samba" está exatamente no esforço de "anulação da distância" e sua frustração ao figurar de maneira cindida, na medida em que a matéria popular não se amalgama com a forma erigida em bossa nova, sustentada pelo indivíduo.

Ainda assim, o samba não é anulado como "promessa de felicidade". Sua determinação bossanovista, ainda que se sobreponha à matéria popular, não elimina o apontamento para um final diferente, que desarme o lastro social definidor do conteúdo cancional. O que está figurado em "Tem mais samba" é o limite histórico de uma forma, sua desinência de classe e, assim, a fisionomia de uma época (ou, ao menos, de uma parte importante dela).

Quando se exige da bossa nova um contato com o samba (que é ele mesmo uma expressão cancional), tomado em seu caráter de matriz popular que acende a estatuto político, a "promessa de felicidade" da reconciliação de antagonismos presente naquela perde qualquer lastro interno à forma cancional, tendo em vista que o sentido centrado no indivíduo da "anulação da distância" se superpõe à “preocupação popular". Revelada a fissura da "promessa de felicidade" em seu caráter bossanovista, a matéria social fica flutuando sem suporte expressivo que lhe dê forma - ou ainda, figura-se a irrelevância de fundo da matéria social para o padrão BASTOS, Manuel D. "Pouco tenho a dizer além do que vai nestes sambas": o sujeito brasileiro e a suspensão da "promessa de felicidade" em algumas canções do primeiro LP de Chico Buarque. Música Popular em Revista, Campinas, ano 2, v. 2, p. 7-36, jan.-jun. 2014. 
bossanovista de modernidade cancional, expondo a reconciliação de contrários como o pedágio nacional a ser pago para adentrar no rol dos grandes feitos da música popular no mundo.

À revelia do compositor, que esperava demonstrar o acerto estético do uso da bossa nova como suporte cancional para a mensagem política, o esforço em erigir a matéria popular em conteúdo pleno, ao esbarrar nos limites formais do estilo, revela não só os fundamentos ideológicos da trilha sonora nacional-desenvolvimentista, como ainda a reincidência engajada.

\section{Meus pobres enganos}

Um dos princípios formais decisivos de "A Rita" está na relação de sincronia e defasagem dos ritmos verbal e musical da canção. Analisando esta relação de perto, podemos afirmar que ela se constitui por meio de uma ambivalência nos acentos rítmicos dos períodos verbais e musicais, em que nenhum assume preponderância sobre o outro, formando com isso uma unidade do diferenciado. Por exemplo, o fluxo verbal dos primeiros versos ("A Rita levou meu sorriso / No sorriso dela / Meu assunto / Levou junto com ela / E o que me é de direito / Arrancou-me do peito / E tem mais etc.") sugere diferentes formas de interpretação - em um caso, justapõem-se os dois primeiros versos como um período ("A Rita levou meu sorriso no sorriso dela"), os seguintes como os períodos subsequentes, sempre em pares de versos ("Meu assunto levou junto com ela"; "E o que me é de direito arrancou-me do

peito"); noutra chave, podemos reconhecer o primeiro verso como isolado ("A Rita levou meu sorriso") e os três versos seguintes como um período imediatamente deste desdobrado ("no sorriso dela meu assunto levou[,] junto com ela"), e os dois versos seguintes como outro período ("e o que me é de direito arrancou-me do peito"); podemos ainda sugerir que, na esteira da possibilidade anterior, o segundo período se resuma a "no sorriso dela [levou] meu assunto" e outro período em "[e] levou junto com ela o que me é de direito". 
A prosódia poética, em que o trabalho de pontuação e organização de períodos não se fecha ao decurso padrão da sintaxe normativa, não subjuga o sentido das estrofes à mera justaposição de versos, na medida em que o desenvolvimento verbal progressivo, lógico e encadeado encontra-se em suspenso, adquirindo validade a tensão entre significados, que ganham sentido apenas na lei interna de seus procedimentos poéticos (metrificação, rimas etc.) - assim, num sentido literário, é preciso procurar as determinações poéticas como fundamentos formais para compreender o sentido de "A Rita". Por exemplo, a rima de "direito" com "peito" exprime reciprocidade entre o mundo humano do ordenamento com o mundo humano do sentimento. As aliterações de "retrato", "trapo" e "prato" reúnem objetos triviais e concretos que, assim em identidade garantida pela exposição em sequência dos termos com emparelhamento de sons, se comparam com os termos anteriores (de "sorriso" a "peito", passando por "assunto" e "direito"), todos condizentes com alguma ordem de abstração do ser, em si mesmo ou social, justapondo objetos mundanos e determinações ontológicas (metafísicas ou históricas). E assim por diante, encontramos nos pormenores técnicos da canção, em seu aspecto literário, dinâmicas cuja contradição das partes se resolve na ambivalência determinada pela convivência delas.

Em se tratando de uma canção, não é demais afirmar também que a organização do decurso musical é determinante nesta construção de sentido. Assim sendo, o desdobramento rítmico dos períodos verbais aflora como elemento de musicalidade poética e é na conjugação deste termo com a música ela mesma que se encontra um fundamento da canção. Por isso, é possível perceber que o fraseado musical, a dinâmica rítmica da canção, nos leva a interpretar o aspecto verbal do primeiro verso como fechado em si e gerador dos demais por desdobramento de sua temática (poética e musical). "A Rita levou meu sorriso"; "No sorriso dela meu assunto"; "Levou junto com ela (e) o que me é de direito, arrancou-me do peito e tem mais" e assim por diante - neste terceiro período, seguindo a prosódia musical, ainda dormita a ruptura de elementos verbais, de sorte que ela guarda em si a finalização de um período ("levou junto com ela" como o significado de "meu assunto", o que cria já também uma disjunção do período anterior), que pode ser compreendido também 
como o início do período seguinte ("levou junto com ela" aquilo que "me é de direito"). Estes procedimentos poético-musicais não fecham os períodos a um só sentido, de sorte que o diferenciado aparece em uma unidade, cuja coesão se dá não pelo sentido fechado, mas por sua indecidibilidade. Interpretando os períodos assim cindidos em nós, por sua vez fracionados e reorganizados em novos nós, a unidade (do diferenciado) de sentido ganha nova importância.

Como se sabe, estamos diante de um discurso fundamentado no eu-lírico que, na presença de outro eu (Rita, que, sendo personagem, não ganha contornos dramáticos por não ser apresentada em diálogo), define o mundo por mediação apenas a si mesmo. Ou seja, este indivíduo nos aparece pelo influxo do eu-lírico, que é quem determina a partir de si as feições do outro. Mas, a depender do acento rítmico compreendido, este eu-lírico ganha relação diferenciada de reciprocidade ou distância com relação ao outro eu que é Rita. Vejamos: quando o período poético-musical é interpretado de maneira a se organizar em uma pequena unidade de sentido os versos "A Rita levou meu sorriso no sorriso dela" e em outra unidade os versos "Meu assunto levou junto com ela", temos uma relação de distância entre o eu-lírico e o outro eu, dado que Rita leva para longe do eu-lírico determinações particulares suas; estas não dependem do outro eu, mas são por este alienadas do eu-lírico. Por outro lado, se as unidades de sentido se apresentam como "A Rita levou meu sorriso", entendida como unidade originária, e "no sorriso dela meu assunto", bem como "levou junto com ela [e] o que me é de direito [e] arrancou-me do peito" como seus desdobramentos, ressalta-se uma dependência da constituição do eu a partir do outro eu (o assunto do eu-lírico está no sorriso dela), e em seguida retornamos ao vazio e distância deixados pelo ato de Rita em levar e arrancar do eu-lírico feições dele. Neste caso, mais denso do que o primeiro, posto que convivam no mesmo fluxo de significação diversas relações entre o eu-lírico, suas feições individuais e o outro eu, a contraditória relação entre ritmo verbal (poético) e ritmo não-verbal (musical) mostram em uma unidade a tensão ambivalente de sentidos diferenciados. É este caso de tensão entre letra e música, em que uma não se reduz à outra, que a dimensão total da canção pode ser intuída. Ela indica a complexa relação entre os indivíduos como expressões do sujeito 
cerne da canção. Esta subjetividade se dimensiona a partir da intrincada relação que o eu-lírico determina com Rita, o outro eu.

Em princípio o eu-lírico, como medida de todas as coisas, deveria ser o cerne constitutivo da subjetividade que se expressa na canção. Porém, em "A Rita" ativa-se outra dimensão deste eu-lírico, em tensão com a primeira, posto que o cerne em última instância da canção, dado por este eu, determina-se a partir de outro eu, próximo e ao mesmo tempo distante. Portanto, Rita adentra numa unidade que não se fecha apenas em sua mediação a partir do eu-lírico, mas este também só tem sua subjetividade definida por meio da compreensão do outro eu que é Rita. O fundamento decisivo do eu-lírico apresenta-se na configuração do outro eu (o assunto do eu-lírico é o sorriso de Rita; não por outra, a canção chama-se exatamente “A Rita”). O eixo central da canção está no fato de que Rita é concomitantemente sujeito e objeto (mas, de $q u \hat{e}$ ?). Porém, se esta definição do eu-lírico no outro eu fosse pacífica, estaríamos diante do mero jogo apaixonado de projeção de afetos. Acontece que este processo de determinação não é instruído sem atribulações - não é a mera expressão de Rita por meio do eu-lírico. Pelo contrário, somos colocados in media res no conflito entre o eulírico e o outro eu. A dependência e a diferença entre o eu-lírico e o outro eu se dão por meio do contraste de interesses; o eu-lírico se prende ao outro para tomar deste uma nova distância que não aquela definida pelo ato de liberdade de Rita em terminar (unilateralmente? sem motivos?) o enlace amoroso.

Nem só das alturas metafísicas da subjetividade vive a forma da canção, “A Rita" em especial - pelo contrário, seu caráter mais rés-do-chão, que não exclui as paragens do ser, exige a contrabalança da materialidade e sua determinação histórica tanto contingente quanto profunda. Sendo assim, algo de imediato se coloca para nós, desde o título da canção, que em princípio deve estar organizada para respondê-la: Quem é Rita? A imagem que temos dela não é das melhores. Seu ex-amante (o eu-lírico), que nos deixa um tantinho de sua paixão (por Rita?) à mostra, nos canta uma mulher que lhe tirou tudo o que possuía. Desde um sorriso, até o disco de Noel, passando pelo coração, Rita levou consigo tudo o que objetiva ou subjetivamente caracterizaria o examante. Sem a alegria desprovida de seu conteúdo que seria o sorriso de Rita, e outras coisas mais, o ex-amante nos dá não só uma boa imagem de si (pelo recurso do eu- 
lírico como centro das atenções), na qual reconhecemos uma pessoa sensível e inteligente, além da juventude estiolada pelo golpe do abandono, como também a figura de Rita como uma mulher mesquinha, capaz de cometer o papelão de levar consigo até objetos irrelevantes. Deste ponto de vista, estamos inicialmente diante da enumeração levemente rancorosa do ex-amante que contabiliza "perdas e danos" do fim do amor e pelo qual somos levados a sentir uma enorme piedade pelo sofrimento causado a ele por Rita. O eu-lírico não exige piedade, nem é piedoso consigo mesmo, mas todo o percurso cancional está interessado em demonstrar sua simpatia. Voz mansa, despojada, simples, numa alegria que disfarça o rancor das palavras, a imagem que a canção nos dá casa muito bem com a figura duplicada de Chico Buarque na capa do disco em que "A Rita" foi gravada - belo, olhos claros, cabelos bem penteados, sorriso bonito, um bom moço, enfim, de quem ninguém duvidaria. O resultado final não poderia ser pior: na presença do violão mudo deixado por Rita, com o que se esvai toda a poesia e sentimento que deveria pulsar antes do ocorrido, só podemos supor que ela é uma mulher impiedosa, impetuosa, vil - para não irmos muito além do bom tom na adjetivação. A audição superficial está assim completa: Rita é uma megera que deixou para trás, desconsolado e sem nem ao menos seus sentimentos mais íntimos, um ex-amante sensível, jovem e tão mais sem posses depois que foi largado à míngua.

Mas, o próprio ex-amante deixa escapar rapidamente o motivo porque Rita matou o amor deles: vingança. Além da ponta de ciúme que o ex-amante deixa escapar, já que por certo Rita levou tudo o que lhe tirou para um outro (mas, seria certo mesmo?), ele sem querer apresenta assim o real motivo do fim do amor: se Rita está se vingando, é porque o ex-amante fez algo. Mas, diante de toda a boa imagem que o ex-amante nos deixou de si, como supor que esta vingança se deu por motivos torpes, sobre os quais ele não tinha nenhum controle e, na verdade, dos quais era inocente? Aqui a artimanha do ex-amante se mostra mais complexa do que podemos supor - mesmo na brecha que ele dá, ainda há uma maneira de vê-la como positiva para ele. O desdobramento da canção, do começo ao fim, não é injurioso, não se trata de alguém com uma bruta dor de cotovelo lançando impropérios de baixo calão contra a mulher que lhe deixou na rua da amargura, ainda que o ex-amante vá deixando aqui e ali os motivos para que nós, ouvintes, tenhamos a pior avaliação possível de Rita e despejemos em sua direção 
adjetivações cruéis. O ex-amante não se apresenta, não nos diz quem é, só sabemos o nome de Rita e pelo comportamento posto em dúvida dela é que retiramos a boa imagem dele: jovem, sensível, religioso, sem muitas posses. E, como só temos Rita como objeto de análise (aliás, desde o início somos instados a isso, pois, como já dissemos, o samba se chama "A Rita"), é nela que centramos o foco da audição, perscrutando de cima a baixo seu comportamento reprovável, do qual temos um péssimo juízo de antemão, enquanto não dirigimos em nenhum instante nossa mínima desconfiança para o ex-amante. Assim, somos levados no papo por uma pessoa de quem não sabemos nem mesmo o nome e nos alinhamos com sua percepção dos fatos. Estamos diante de um muito refinado e experto malandro, que quer determinar, a partir de seu ponto de vista interessado, a compreensão do caso, direcionando contra Rita os olhares críticos ao mesmo tempo em que, sem alarde, faz de si uma boa imagem, e sem dar alternativa ao ouvinte para compreender o ocorrido. Assim como na capa do disco, ao lado do bom moço há sua outra face, aborrecido, ainda que não raivoso. Sua principal estratégia é adotar o eu-lírico como verniz de boas intenções, para não atrair atenção para seu fundo inconfessável. Aqui a poesia serve como forma de dar expressão, mais especificamente revelar os termos de um discurso opressor.

A música que dá ossatura à canção é um samba suave, mesmo sensual, próprio para ser dançado na gafieira, local, aliás, que seu narrador possivelmente frequentaria. Ela sugere o tom das afirmações do ex-amante, a quem já podemos chamar de sambista. A ginga de corpo, ao mesmo tempo sutil e firme, com que o sambista dança no salão, está presente nos meneios da canção, naquela dinâmica ambivalente e nela acentuam um brilho vistoso que podemos nomear de charme. Assim, toda a estratégia cancional do sambista baseia-se neste charme que ele joga para o ouvinte, em favor de sua narrativa e em detrimento da imagem de Rita. Como geradora musical do malandro, o samba de fundo logo indica para quem quiser ouvir que o narrador não é uma pessoa absolutamente confiável, ainda que nos lance todo o encanto charmoso para despistar suas intenções de fundo. É a esse encanto que não se pode ceder na audição crítica - é essa audição que cede ao charme do sambista que se espera no seio mesmo da indústria cultural. A audição que aqui se propõe incorpora aquela que cede ao charme do sambista, mas o faz a contrapelo, para mostrá-la não só 
como parte interessada, mas também como parte de uma forma cancional que indica mais do que aquilo que está na superfície. Então, temos uma audição proposta pelo ex-amante, se aproveitando também da credibilidade que a indústria cultural lhe dá como estrela principal e do eu-lírico como fundamento poético vistoso, nobre e de quem ninguém desconfiaria, e pequeníssimas, porém fundamentais, brechas para estipularmos uma crítica ao ponto de vista apresentado.

Convém perceber que a narrativa em dor de amor do sambista ex-amante vem com boa dose de pronomes possessivos (meu, seu), bem como de termos que indicam posse (dela, "levou junto com ela", herança, tostão - que não levou porque "não tinha não" -, "perdas e danos"). O fundo da lamentação do ex-amante, que fala de amor e coração de forma comovente, diz respeito exatamente à destinação das posses - como quem, ao perder para a companheira aquilo que foi conseguido junto (ou enquanto se matinha uma relação), dá a cada coisa um valor acrescido de rancor e discórdia. Porém, se nos livrarmos finalmente do psicologismo como caminho de interpretação, perceberemos que tais rancor e discórdia, que se nos apresentam como oriundos do mal de amor, não deixam de ser também, ao revés, o desespero pela perda da propriedade. Rita é a protagonista do esfacelamento das parcas posses do examante. Entendida (pelo ex-amante e por aqueles que o seguem na audição) como uma delas, Rita encabeça a rebelião empreendida contra um proprietário, o que é muito mais do que um ataque desferido contra o amor. O coração que sangra e lamenta a perda da poesia é aquele que nos induz pelo charme, que não mostra um pingo sequer de desconsolo (a música é levemente animada, o que realça ainda mais a necessidade de desconfiar deste malandro); quando ele entra no assunto vingança, os termos da posse, que já haviam sido anunciados anteriormente de passagem (primeiro, referindo-se ao direito sobre a propriedade, em seguida enunciando objetos levados por Rita), entram em primeiro plano (herança, tostão, perdas e danos). Habilmente, porém, com a malandragem e o charme peculiares, o sambista ex-amante desenrola o problema da propriedade, calmamente, até chegar ao emudecimento do violão, o que equivale dizer que ele ficava assim esvaziado de suas qualidades poéticas. Mas, não estamos exatamente ouvindo uma canção dele? Neste sentido, o argumento liricizado do sambista tenta nos induzir ao desenrolar da história que leve da depredação de suas 
posses até o fim arrasador em que juventude, sentimentos e sensibilidade poética deixam por isso de existir para ele. A contrapelo, porém, a história muda de figura e podemos enxergar o lirismo como o véu que esconde o ódio que o sambista passou a nutrir pela decisão de Rita em abandoná-lo. Amor e ódio, aqui, são expressões da relação de propriedade que se estabelece entre os dois. Todo aquele problema do indivíduo (do eu e o outro eu), aqui ganha uma figura histórica. Assim, o ato de Rita fere a masculinidade do sambista como forma de expressão da lógica do proprietário - é, portanto, a crítica a uma dinâmica de classe.

Não se trata de reduzir ao antagonismo de classes a atitude firme da mulher contra o homem que lhe minora. O que está em jogo é perceber como tal antagonismo é fundamentado em dinâmicas sociais que não se fecham apenas nos dilemas de classe e que, assim, destes fazem parte, ampliando-o. O patriarca, enquanto máscara social acabada do proprietário, se cristaliza mesmo em quem não detém posses e é esta posição que o sambista assume quando Rita lhe deixa à míngua. Portanto, não é uma posição econômica, mas uma expressão da cisão social causada pelos imperativos da esfera econômica. Aquele eu-lírico que se aproxima e se distancia do outro eu é a expressão de um antagonismo social. A audição a contrapelo, assim, completa um argumento crítico, que sai do discurso charmoso do sambista ao seu desvelamento como discurso interessado e expressão de classe sedimentando em quem, em princípio, não deveria empunhá-lo. Não há dúvida, portanto, que o adocicado veneno do discurso patriarcal, envolto em plumas líricas, é um raciocínio de classe; enquanto tal, incorporado por alguém que dista dos proprietários (o que só pode operar como suposição, pela ausência de maiores indicações; mas, em se tratando de um samba, e pelo apontamento da falta de dinheiro, é razoável manter a hipótese), o gesto de raiva, encoberto pela sutileza e mansidão do samba e seu tom lírico, joga no polo oposto ao da urgência social dos espoliados, de quem Rita é uma figura.

\section{Indivíduos entre si}

Quando Adélia Bezerra de Meneses (2000) aponta o lirismo (nostálgico) do primeiro Chico Buarque como sua principal substância, ela está amparada num BASTOS, Manuel D. "Pouco tenho a dizer além do que vai nestes sambas": o sujeito brasileiro e a suspensão da "promessa de felicidade" em algumas canções do primeiro LP de Chico Buarque. Música Popular em Revista, Campinas, ano 2, v. 2, p. 7-36, jan.-jun. 2014. 
fundamento objetivo encontrado na própria obra analisada, ainda que não deixe escapar a determinação história do mesmo. Na medida em que o lirismo se define pelo eu (lírico) como mediação do mundo, a figura do indivíduo emerge para primeiro plano como ponto culminante do conhecimento estético. O apontamento é correto, mas não encara de frente o perfil ideológico do problema. Em vez de reduzirmos ao psicologismo ou ao ser abstrato esta série de indivíduos que aparecem ao longo do primeiro momento da obra de Chico Buarque, podemos compreender esses indivíduos como expressões variadas e contraditórias do sujeito brasileiro, ou seja, a precipitação de um conteúdo histórico. O fundamento lírico não pode ser tomado ao pé da letra, sob pena de se cair na armadilha ensejada por partes interessadas na luta gerada pelo antagonismo social que se apresentam como detentores do eu-lírico. É nas semelhanças e nos contrastes desses indivíduos entre si que poderemos encontrar uma face do sujeito brasileiro como expressão histórica de uma época, pela forma que as canções de Chico Buarque oferecem.

Assim, podemos perceber que Rita, observada como elemento inicial de comparação, se conjuga com uma série de outros indivíduos que se fazem presentes nas canções de Chico Buarque neste primeiro período. Às vezes, tais indivíduos têm nomes próprios (Madalena, Pedro, Juca), por vezes são apenas pronomes ("Ela e sua janela", “Você não ouviu”, "[Eu] estava à toa na vida”, caso de sujeito oculto que busca exatamente passar despercebido no meio dos demais indivíduos). Na maioria dos casos, seu substrato musical é alguma derivação bossanovista e apenas em raríssimos casos são sambas - o que implica uma relação contrastante entre o primado da melodia bossanovista (que ecoa nas canções mesmo que não esteja presente enquanto fundamento musical e que representa a parte do indivíduo em contraste com a sociedade) e a coletividade que se expressa pelo ritmo do samba. Por vezes, tais indivíduos formam pares: a mulher de "Ela e sua janela" paga um castigo e cuida de sua filha, enquanto imagina onde estará o pai da criança, que presumivelmente as largou ao deus-dará; mas Madalena, na canção logo em seguida, vinga esta mulher e vai para o "mar", deixando o marido "vendo navios" e, como narrador da canção, clamando pela volta da esposa, a fim de que ela cuide dos filhos. (E não é demais destacar que ambas são subsequentes à Rita.) Em outros casos, estes indivíduos 
entrecortam temáticas fundantes das canções: em "Amanhã, ninguém sabe", o cantor avisa que segue passionalmente ligado ao samba, já em “Olê olá”, o samba que abunda não é dançado por ninguém, o que justifica a tristeza da ouvinte-intérprete. As ressonâncias são variadas, de maneira que elas vão organizando um ambiente comum de problemas dos quais os indivíduos aparecem como portadores ao circular entre eles. Já os títulos se referem aos indivíduos tanto quanto às matérias: "A banda”, “Tem mais samba", "A Rita”, "Ela e sua janela”, "Juca” etc. etc.

Em princípio, a inflação de indivíduos particulares deveria nos prender à particularidade mais íntima como temática principal das canções de Chico Buarque. Creio não ser despropositado sugerir que a análise de Adélia Bezerra de Meneses de alguma forma se baseia nesta premissa, dando especial atenção ao indivíduo que sugere como inexorável o eu-lírico que fundamentaria o lirismo nostálgico da obra em questão. Assim, mesmo quando a matéria objetiva da canção se sobressai ao indivíduo, a análise fundamentada no eu-lírico busca repor o assunto nos limites da particularidade do indivíduo, em sua interpretação a mais abstrata possível, quando não meramente psicologista. Então, com o lirismo nostálgico, não estamos diante da compreensão da matéria objetiva mediada pela subjetividade cristalizada no indivíduo, mas no indivíduo como centro último de toda a matéria. Como já vimos em outros termos mais acima, tal força de pressão do indivíduo sobre a matéria das canções é historicamente determinada - não se trata apenas de uma estruturação do ser universal, nem mesmo a mera aparição fenomênica da singularidade que expressa de maneira psicologista o mundo por meio de si; sendo isso também, é preciso reconhecer a presença da determinação histórica, tanto contingente quanto mediada, especificamente de uma concepção cancional (a bossa nova), por meio da qual a matéria das canções se formaliza. Ainda assim, na medida em que a compreensão da obra de Chico Buarque por meio do lirismo aponta para a necessidade de atenção especial ao eu-lírico, acabamos por perceber o caráter crucial que o indivíduo, portador da palavra cantada nas canções, determina em sua fatura. De qualquer modo, deve se levar em consideração que os diversos aspectos da matéria cancional (desde o amor até o samba) giram não apenas nos determinantes abstratos da forma estética da bossa nova, mas em um conteúdo estético (portanto, mediadamente social) que lhe é próprio 
e que se apresenta desde dentro, de sorte que em cada aspecto das canções apresentase a relação entre tais partes. Por isso, nem os diversos indivíduos, nem a matéria social das canções sobredeterminam a organização cancional. O mais exato seria dizer que a conjugação de assuntos e indivíduos entre si apresentam a figuração de uma lógica social. Se assim o é, não será exagero afirmar que estamos diante de uma figuração da subjetividade brasileira, que é uma figura de classe e da qual nos falta a fisionomia histórica.

Se retomarmos o raciocínio para "A Rita", a especulação a respeito do caráter complexo da estrutura cancional por meio da qual se expressa o entrevero entre Rita e o sambista ex-amante em posse do eu-lírico ganha novo aporte. Qual é a relação entre o jogo sinuoso da malandragem do sambista, os entreveros do desenlace amoroso, o anseio pela posse que perpassa as contradições de gênero, de um lado, e a determinação histórica de forma, expressão e conteúdo da obra de Chico Buarque, de outro? O eu-lírico que nos fala é o sambista, centrado em sua posição de indivíduo vilipendiado, que recusa qualquer reconciliação com Rita, aquela que lhe surrupiou as posses, ainda que o ex-amante se mantenha coeso em não atacá-la frontalmente, fazendo jus ao lirismo de seu estilo, levando até o fim a pose e o charme que lhe são característicos. Este indivíduo, em quem se encontra um eco bossanovista, por sua presença leve e parcimoniosa oriunda de seu lirismo peculiar, engendra-se, por sua vez, em um samba propriamente dito. Se o sambista não se reconcilia com quem ele nos apresenta como uma usurpadora, por outro lado ele entra em comunhão com a sutileza do indivíduo bossanovista, que com isso revela uma de suas possíveis facetas. Assim, concretizando negativamente a fundamentação lírica da obra de Chico Buarque, o indivíduo apresenta aí um sujeito cindido. Esperando a reconciliação entre indivíduos singulares como forma de coesão social, conforme a promessa bossanovista que aqui ecoa, temos no reverso o distanciamento destes pela luta em torno da propriedade, em que mesmo os elementos técnicos da canção são uma arma, a ponto de negar à Rita seu lugar subjetivo. O caráter determinado da cisão da subjetividade é a luta pela posse, pela propriedade, em que um indivíduo ancora-se na "promessa de felicidade" para se sobrepor a outro indivíduo, granjeando a simpatia do ouvinte em seu favor. Sujeito e objeto, indivíduos e posses, são a expressão da cisão social e o 
antagonismo resultante. Esta é a estrutura da imagem histórica que temos diante de nós em forma de canção.

Ainda que o queira e assim se apresente, o eu-lírico não determina sozinho o material que está em jogo na experiência cancional, pelo menos no que diz respeito ao primeiro LP de Chico Buarque. Se o eu que se expressa cantando não é fraturado, aqueles que com ele compõem o universo fechado da canção o são, e vice-versa - é na interpenetração de uns nos outros, naquilo em que se suplementam ou completam, que temos a fatura final do problema. Assim, por exemplo, em "A banda" a cisão do eu-lírico, que em aparência é coeso e unívoco, se apresenta na fratura da vida sem sentido dos demais personagens, que em última instância projetam as contradições do poeta-narrador. Em “Tem mais samba”, canta-se o samba como solução para quem sofre, de maneira a fazer o próprio samba ser sacrificado. O dúbio caráter de Rita se apresenta a partir do depoimento do sambista pouco confiável, restando apenas certezas em suspenso. Pedro é um atoleiro de problemas diante de sua interminável espera, que será em vão, como sabemos de antemão. Juca, o personagem caído dos anos 1930 no disco, "autuado em flagrante", tenta convencer o delegado de suas boas intenções, emanadas da figura enigmática de Maria, que não responde à serenata e só se apresenta como espectro, ainda que seja o conteúdo fundador do samba. Os exemplos podiam continuar seguindo à exaustão pelos discos subsequentes. Para o que nos interessa, retenha-se a conjugação de liberdade e contenção de movimento do indivíduo, sua nota de classe.

Voltando mais uma vez a "A Rita", na relação entre o sambista e Rita, o examante se assenta num ambíguo jogo de disputa de propriedades, figurando como a vítima de um processo. Aí, estamos afeitos ao conteúdo da canção. Sua forma, porém, nos revela que o sambista, ao deter a posse da palavra cantada, faz uma figura parcial de Rita, deixando entrever o ressentimento pela perda de propriedades (entre elas, Rita, que, em última instância, teria desencadeado todo o processo). Como não é um proprietário, no que diz respeito a sua posição econômica, mas reconhece o mundo a seu redor a partir das categorias engendradas para justificar a cisão social, o sambista utiliza uma estratégia para lá de ambígua, a fim de afirmar sua identificação íntima com a subjetividade beneficiada pelos antagonismos históricos ao mesmo tempo em 
que nega qualquer posição subjetiva a Rita, enxovalhada à vala de um indivíduo sem caráter. Não que Rita não seja reconhecida positivamente como um indivíduo (a música leva seu nome, suas diversas ações são narradas ao logo da canção, estas são reprovadas pelo sambista etc.) - mas, este reconhecimento tem por fundo a negação da subjetividade deste indivíduo, ou, para ser mais exato, a subjetividade em jogo não reconhece em si o indivíduo Rita. A relação destes indivíduos entre si é, sem tirar nem pôr, a expressão do fundamento social brasileiro.

Em “A Rita" figura-se o gesto de liberdade de Rita ao mesmo tempo em que se contém esse ato baixo o signo da vingança; o sambista, por sua vez, apresenta o livre desdobramento da opinião fundamentada na posse do eu-lírico. A liberdade de ação de Rita só se apresenta negativamente, ou seja, pela percepção depreciativa que desta tem o ex-amante, que apresenta ele também uma fluidez de movimento (e espírito) ao lamentar a perda de propriedades, porém, tomando para si a posse da palavra cantada. Esta é a cesura da subjetividade herdada da bossa nova em encontro com os indivíduos que circulam pela matéria social da obra de Chico Buarque. Colocada em contraste com o contexto imediato que lhe define, a figuração cancional apresenta novos elementos, posto que a contingência histórica de ditadura militar nos anos 1960 ampara-se no jogo contraditório de liberdades individuais suspensas em suposto favor da reconstrução da democracia. Este preceito das liberdades individuais, nas variadas formas com que se apresenta nas canções de Chico Buarque, mostra-se a partir de uma complexa diretriz de privilégio social, que dá nova figuração ao estatuto do indivíduo alcançado pela bossa nova. Este privilégio, que é por si só um elemento de dominação de classe, aparece, contudo, de forma paradoxal também naqueles que se encaixam na classe dos esbulhados. O sambista, ex-amante de Rita, por exemplo, nos dá a entender que, não tendo tostão, não é propriamente um representante da elite. Porém, pelo avesso, ele faz uso do privilégio de portar a palavra cantada, na qualidade de eu-lírico, para dar de Rita uma imagem sobre a qual não podemos ter certeza - ou seja, sua posição de eu-lírico não-confiável, sendo um estratagema cancional oriundo do privilégio de classe, ganha uma nova dimensão, tendo em vista que se apresenta também junto àquele que, em princípio, não deveria ser seu portador. O cerne do processo histórico sedimentado na obra de Chico Buarque está no privilégio social como um princípio de 
totalidade. Por vezes, este privilégio é uma determinante material de cisão social, por outras ela se apresenta como fundamento ideológico, o que não deixa de ser uma expressão daquela materialidade. Em um ou outro caso (que, em última instância, são expressões do mesmo fundamento), os indivíduos são identificados a partir de sua relação com este privilégio, de forma que a subjetividade a que estamos buscando compreender aqui, em sua figura histórica, tem sua definição nele. Este privilégio se organiza como a pretensa liberdade, estabelecida em estado de exceção, que se conquista sobre os demais - o exemplo em questão é o sambista e a Rita, mas podemos reconhecê-lo ainda na atitude paternalista do eu-lírico narrativo de "A banda", a título de contraste. Assim, os níveis de materialidade desta liberdade de classe conjugam-se com uma espécie de logro ideológico, que integra diferenças sociais, como uma pacificação de contrários que não se apresenta como problema. E, assim, a lição que a obra de Chico Buarque dá para o momento histórico contingente e a experiência em que ela se encontra é: a sensação de liberdade, que se apresenta como uma suspensão do privilégio de classe (como observamos panoramicamente acima nas canções de Chico Buarque), sendo na verdade sua maior realização, já que não modifica a materialidade cindida em que se encontra, revela-se assim como o estratagema de mitigação da luta de classes, ou, por outro lado, sua permanência, por outros meios.

\section{Discografia}

HOLLANDA, Chico Buarque de. Chico Buarque de Hollanda. RGE, CD 4028-2, 1997 (1966).

\section{Referências bibliográficas}

BASTOS, Manoel Dourado Bastos. Solidariedade piedosa: a antinomia estética em “A Banda" (1966), de Chico Buarque. Cerrados. Revista do Programa de Pós-Graduação em Literatura da UnB, n. 21, ano 15. Brasília: 2006. pp. 167-180.

Notas de testemunho e recalque: Uma experiência musical dos traumas sociais brasileiros em Chico Buarque e Paulinho da Viola (de meados da década de 1960 a meados da década de 1970). Doutorado em História. Assis/SP, Faculdade de Ciências e Letras, Universidade Estadual Paulista, 2009. 
Pressentimento da promessa de felicidade: o "samba da desilusão" de Paulinho da Viola. Revista do Instituto de Estudos Brasileiros, n. 57, p. 299-324, 2013.

GALVÃO, Walnice Nogueira. MMPB: Uma análise ideológica. In: Saco de gatos. São Paulo: Livraria Duas Cidades: 1976.

GARCIA, Walter. Bim Bom: a contradição sem conflitos de João Gilberto. São Paulo: Editora Paz e Terra, 1999.

. "Radicalismos à brasileira”. Celeuma, n. 1, vol. 01, mai. 2013.

MAMMİ, Lorenzo. João Gilberto e o projeto utópico da bossa nova. Novos Estudos CEBRAP, n. 34, pp. 63-70, nov. 1992.

MENESES, Adélia Bezerra de. Desenho mágico: poesia e política em Chico Buarque. $2^{a}$ edição. Cotia (SP): Ateliê Editorial, 2000.

WERNECK, Humberto. Gol de letras. In: Chico Buarque: Letra e Música 1. São Paulo: Companhia das Letras, 1989. 